\title{
The Impact of Job Satisfaction with Intrinsic Factors and Employee Performance. A Case Study of Food Industry
}

\author{
Sumra shaikh* \\ $\mathrm{PhD}$ Research Scholar, University of Sindh, Jamshoro, Pakistan \\ Banglow C\# 63, Near Wamique Manzil, GMB colony, Qasimabad, Hyderabad, Sindh, Pakistan \\ Haseeb Shaikh \\ Engineer, Civil department, Mehran University of Engineering and technology, Jamshoro and Sr. Estimator \\ Engineer at Riyadh Metro Project - Riyadh Saudia Arabia \\ Riyadh Metro Project Oruba Site Complex, Oruba Road, Salah Ad Din District, P.O Box 66601 Riyadh, 11586 \\ Saudi Arabia \\ Sumair Shaikh \\ Engineer, Mechanical department, Quaid e Awam University of Engineering, Science and technology, \\ Nawabshah,Pakistan and Maintenance Manager Javedan Corporation Limited \\ Admin building Naya Nazimabad, Manghopir road Karachi, Sindh, Pakistan
}

\begin{abstract}
The objective of current paper assess the effects of job satisfaction on intrinsic factors as well as performance of employees. Current thesis applies Herzberg's two-factor theory to investigate the effects of job satisfaction on intrinsic factors and employees performance. Seven point Likert scale is employed for survey purpose. Reliability test, Pearson correlation, Analysis Of Variance (ANOVA), $t$ test and multiple regression techniques are engaged for data analysis. In food industry, the result shows that job satisfaction factors effects positively to each other and intrinsic factors. The results also deliberated the positive impact on employees' performance. This study contributes large amount of knowledge on the significance of job satisfaction for improving the employees' performance.
\end{abstract}

Keywords: Job satisfaction, Food Industry, Intrinsic factors, Two-factor theory, Employee performance

DOI: $10.7176 / \mathrm{EJBM} / 11-13-07$

Publication date:May $31^{\text {st }} 2019$

\section{INTRODUCTION}

According to Adnan (2003), satisfaction of employees is one of the great issue in organization. Employees are main asset of every organization. Organization success cannot achieved without employees therefore; organizations have given priority to employees. Food industries are one of them. Many organizations cannot understand the meaning, significance and importance of satisfaction of employees. Herzberg two-factor theory deliberated that level of satisfaction of employees can increased, motivated and satisfied by motivators. The motivators of two-factor theory of Herzberg are advancement, achievement, recognition; work itself and growth (Khan et al., 2014).

Job satisfaction contributes a great role on employees' performance in food industry. Satisfaction of employees is an important issue for all organizations including the food industry. The food industry is focused to improve the productivity, enhance standard of customer services, effectiveness and controls.

Food industry increases the satisfaction level among employees through participation and encourage their ideas that ultimately increase their value in the organization. Food industry enhances their employees' performance, which ultimately motivate the organizational performance.

\section{LITERATURE REVIEW}

Job satisfaction is necessary for successful and competitive strategies of the organization, which increase the efficiency of employees and make them relaxed (Yim et al., 2018). Job satisfaction is contributing a leading role in improving the levels of performance and career development (Suprianto et al., 2018).

The hope of employees from the organization is to provide them appropriate training courses to increase the level of satisfaction (Maksuc, 2016). According to Rias et al., (2017), Rockmann et al., (2017), Turner, A., (2017), Bear et al., (2017), Brehma et al., (2017) and Maksuc (2016), job satisfaction comprises certain areas, for example, good amount of pay, opportunities, rewards, security of jobs and flexible workplace.

Job satisfaction is defined as an individual feeling regarding their work (Aziri, 2011). Job satisfaction factors are contributing imperative role for satisfaction of an individual and the organization (Ali et al., 2008). Organization should have to provide good salary, promotions and training facilities to employees for increasing their satisfaction levels (Jones \& Sloane, 2007). 
Job satisfaction is providing the best services to their employees at workplace (Nguyen, Taylor, \& Bradley, 2003; Robbins \& Judge, 2003). According to Ruthankoon (2003), job satisfaction is key of successful organizations. Previous studies mostly found that the strength of an organization depends upon the level of workers' satisfaction (Shikdar \& Das, 2003; Wright \& Cropanzano, 1997). Job satisfaction increases the importance of the work itself (Amabile, 1993). Job satisfaction is achieved by multiple factors rather than single factor (Spector, 1997).

Herzberg (1959) discussed motivation from two different perspectives of job satisfaction as motivators and job dissatisfaction as hygiene factors (Stello, 2012). According to May (1978), job satisfaction is same as motivators or content factors and highly applied in the administration. According to Herzberg (1959), motivators increase the strength of job satisfaction. Job satisfaction is a technique to make employees good and relax concerning their responsibilities and job (Herzberg, 1959). Appreciation of employees related their job arise positive impact to job satisfaction (Locke, 1976). According to May (1978), advancement, achievement, work itself, recognition and growth are motivators of Herzberg's two-theory, which increases the level of satisfaction among industrial employees.

Employees are more satisfied through opportunities, good recognition, growth, achievement, positive feedback, good policies, security of a job, loyal relations and flexible workplace (Palaniammal, 2013). Affirmative behavior from administrators increases the satisfaction of employees, which ultimately causes retains and progress of employees' performance (Mahfood, 2012). For enhancing the productivity, organizations ought to pay thoughtful attention to work environment. Interactions among human (peers or administrators) are crucial sources of job satisfaction (Chandrasekar, 2011). Job satisfaction creates positive feelings that arise from the assessment of an individual's experience of work (Hasibuan, M. 2009).

\section{METHODOLOGY}

In current thesis, research methodology is very important portion for analysis of data. The data was gathered through questionnaires. For this purpose, 485 copies of questionnaire were collected from food industry. Reliability test was conducted through SPSS version 20.0. Pearson correlation, $t$ test, ANOVA and multiple regressions techniques were used for analysis of data. In this regard, Jarque Bera test employed. On basis of Jarque Bera, all variables used in multiple regression were normally distributed. Convienence non probability technique and random sampling techniques were used in present study. The selected area is Hyderabad, Sindh.

\section{RESULTS AND DISCUSSIONS}

\subsection{DEMOGRAPHIC INFORMATION OF FOOD INDUSTRY}

The details about demographic information regarding food industry are given below.

The first category is gender, in food industry there were 100\% male. Food industry were taking interest for hiring the females because of personal pregnancy issues.

Age is second part of information that represented highest ratio of percentages consisted of $57.1 \%$ employees belonged to age group of 41-50 years because high age of employees have more knowledge to face the hurdles related to industries while $28 \%$ were concerned with $31-40$ years, $12 \%$ were related to $21-30$ years and $2.9 \%$ were age of more than fifty years.

Work experience demonstrated that $59.4 \%$ workers had more than 15 years' experience. Experts create positive impact for industrial growth and economy of country while $29 \%$ had 10 years and $11.6 \%$ had 5 years.

Permanent rate of employees in food industry were $94.9 \%$ while on contract there were $5.1 \%$ workers.

For education point of view, in food industry $51.1 \%$ workers were bachelors, $36.9 \%$ workers were master, $9.9 \%$ workers were college and $2.1 \%$ workers were high school and other professionals.

Marital rate were $98.0 \%$ workforces while $2 \%$ were unmarried.

\subsection{ANALYSIS OF JOB SATISFACTION WITH INTRINSIC VARIABLES FOOD INDUSTRY \\ 4.2.1 Descriptive statistics}

Job satisfaction (JS) consists of three item statements: question 32, 33 and 34. The descriptive statistics of job satisfaction are in tables 1 and 2. Descriptive statistics have tested for this research for individual variable and for all variables as well. Job satisfaction has 3 items. The individual and overall mean of all items of job satisfaction are above 5 and near to 6 which has shown that all items have near to degree of agreement.

\subsubsection{Reliability Test of Job Satisfaction of Food Industry}

Reliability test of job satisfaction are given in table 3. Cronbach alpha have tested for this research for all variables. Job satisfaction has 3 items and the overall cronbach alpha of job satisfaction are statistically good results. The results have recommended that data have internal consistency and have applied for proceeding the analysis.

4.2.3 Pearson Correlation of Job Satisfaction with Intrinsic Variables of Food Industry

Pearson correlation of food industry job satisfaction are mention in table 4. In food industry, the correlation 
shows all positive values. The result shows that all the intrinsic variables as independent variables effects positively to each other and job satisfaction. The job satisfaction is closely related with work itself (.519) and then following recognition (.506), growth (.488), achievement (.391) and is less closely related with advancement (.387). According to Pearson correlation effects in food industry, work itself and recognition have moderate relationship while growth, advancement and achievement have small but definite relationship with job satisfaction

4.2.4 Pearson Correlation of job satisfaction and employee performance

Pearson correlation of job satisfaction with employee performance is given in table 5.The pearson correlation shows positive value and there is high correlation between job satisfaction and employee performance.

4.2.5 Multiple Regression Of Job Satisfaction With Intrinsic Variables Of Food Industry

Multiple regression of food industry regarding job satisfaction are represented in tables 6 . In this model, the strong point of association value of correlation coefficient is $76.2 \%$ large, showing strong relationship between intrinsic factors with job satisfaction. The coefficient of determination is mentioned by $\mathrm{R}$ square is 0.581 and Adjusted $\mathrm{R}$ square is .580. This model have explained the variance which described that five independent variables have explained $58.1 \%$ of variation in job satisfaction.

By measuring through ANOVA, the F-statistic is 1201.075, which show high strength of model. As a result, the model has given a good description of association among explained and unexplained factors.

From the Coefficient's table, among all intrinsic variable, growth has more importance with its t-test is 26.058 and Beta is 0.531. Then work itself is second most significant independent variable, the third is achievement, the fourth most significant independent variable is advancement and fifth, recognition is significant independent variable. The result indicates that the growth, achievement, work itself, advancement and recognition have positive significant association with job satisfaction.

4.2.6 Multiple Regressionof job satisfaction and employee performance

Multiple regression of job satisfaction with employee performance is given in tables 7 .

The strength of correlation coefficient R, association of job satisfaction with employee performance is 0.993 , this value shows strong correlation. The coefficient of determination is mentioned by R square is 0.986 and Adjusted $\mathrm{R}$ square is .986. This model have explained $98.6 \%$ of variation in job satisfaction.

By measuring through ANOVA, the F-statistic is 295680.597, which show high strength of model. As a result, the model has given a good description of association among explained and unexplained factors.

From the Coefficient's table, job satisfaction has more significance with its t-test is 543.765 and Beta is 0.993. The result indicates that job satisfaction has positive significant association with employee performance.

\section{CONCLUSION}

It is concluded that job satisfaction is a key tool within the organization. Food industry enhances and improves the employee's job satisfaction by facilitating with training opportunities through which they will increase their status, confidence, style of communication and manage the industrial matters. The result demonstrated that performance of employees is extremely motivated that created an affirmative link amongst job satisfaction and employee performance as well as job satisfaction and intrinsic factors that eventually generate good future impact on performance of the industry. The results suggested that high job satisfaction in textile industry also provided the opportunities to take an interest in the job and create effective leadership. The employee turnover rate is much lower due to proper and flexible environment. Food industry saves their money, make effective products and high profit by concentrating on employees' satisfaction.

\section{REFERENCES}

Adnan, A. M. (2003). an Empirical Study of Employee Satisfaction in Textile Industries, (June).

Ali, R \& Ahmed, S.M (2008). The Impact of Reward and Recognition Programs on Employee's Motivation and Satisfaction. A Co-Relational Study. Available at:http://www.academia.edu/309095 [Retrieved: 2013-11$05]$

Amabile, T.M (1993) Motivational Synergy: Towards new conceptualizations of intrinsic and extrinsic motivation in the workplace. Human Resource Management Review, 3(3), pp.185-201

Aziri, B. (2011). Job satisfaction: A literature review. Management Research and Practice, 3, 77-86.

Bear, G. G., Slaughter, J. C., Mantz, L. S., \& Farley-Ripple, E. (2017). Rewards, praise, and punitive consequences: Relations with intrinsic and extrinsic motivation. Teaching and Teacher Education, 65, 10 20. https://doi.org/10.1016/j.date.2017.03.001

Brehma, M., Imberman, S. A., \& Lovenheim, M. F. (2017). Achievement effects of individual performance incentives in a teacher merit pay tournament. Labour Economics, 44, 133-150. https://doi.org/10.1016/j.labeco.2016.12.008

Chandrasekar, K. (2011). Workplace environment and its impact organizational performance in public sector organizations. International Journal of Enterprise Computing and Business Systems, 1(1), 1-19 
Hasibuan, M. (2009). Organisasi dan Motivasi. Jakarta: Bumi Aksara.

Herzberg, F. H., Mausner, B., \& Snyderman, B. S. (1959). The motivation to work. John Wiley and Sons

Jones, R.J \& Sloane, P.J (2007). Low Pay, Higher Pay and Satisfaction in Wales. Wales, Routledge Tayler \& Francis Group Jenica, $P$.

Khan, I., Dongping, H., \& Ghauri, T. A. (2014). Impact of attitude on employees performance: A study of textile industry in Punjab, Pakistan. World Applied Sciences Journal, 30(30 A), 191-197. https://doi.org/10.5829/idosi.wasj.2014.30.icmrp.25

Locke, E. (1976). The nature and causes of job satisfaction. Handbook of Industrial and Organisational Psychology, Chapter 30.

Mahfood. W.V, Pollock. W \& Longmire.D. (2012). leave it at the gate: job stress and satisfaction on correctional staff. A journal of criminal studies. 26(3), 308-325.

Maksuc, F. (2016). Employee motivation and satisfaction: The case of Clinical Centre University of Sarajevo

May, B. R. (1978). A Study of Herzberg's Motivation-Hygiene Theory of Job Satisfaction as It Relates to Academic Personnel in Selected Small Liberal Arts Colleges

Nguyen, A., Taylor, J., \& Bradley, S. (2003). Relative pay and job satisfaction: Some new evidence. $M P R A$, 1382. Retrieved from https://mpra.ub.uni-muenchen.de/1382/1/MPRA_paper_1382

Palaniammal, G (2013) "Motivating Factors of Employees Are Instigated To Improve Organization Productivity". Indian Stream Research Journal, 3 (7), 1-4.

Rias, A. L., Bouchard, C., Segonds, F., Vayre, B., \& Abed, S. (2017). Design for additive manufacturing: Supporting intrinsic-motivated creativity. Emotional Engineering, Vol.5, 99-115. https://doi.org/10.1007/978-3-319-53195-3_8

Robbins, S. P., \& Judge, T. (2003). Essentials of organizational behavior. Upper Saddle River, NJ: Prentice Hall, 7

Rockmann, K. W., \& Ballinger, G. A. (2017). Intrinsic motivation and organizational identification among ondemand workers. Journal of Applied Psychology, 102(9), 1305-1316. https://doi.org/10.1037/apl0000224

Shikdar, A. A., \& Das, B. (2003). The relationship between worker satisfaction and productivity in a repetitive industrial task. Applied Ergonomics, 34, 603-610

Spector, P. E. (1997), Job satisfaction. Thousand Oaks, Sage Publications, California, 11 - 230 Stello, C. M. (2014). Herzberg's Two-Factor Theory of Job Satisfaction: An Integrative Literature Review. Herzberg's Two-Factor Theory of Job Satisfaction, 32. https://doi.org/10.7537/marslsj140517.03

Suprianto P.U., Djoko P. and Zarah P. (2018). The performance of the employee in the persfektif leadership, career development and job satisfaction. International Journal of Recent Scientific Research, 9(7), pp. 28214-28216

Turner, A. (2017). How does intrinsic and extrinsic motivation drive performance culture in organizations? Cogent Education, 4(1). https://doi.org/10.1080/2331186X.2017.1337543

Wright, T. A., \& Cropanzano, R. (1997). Well-being, satisfaction and job performance: another look at the happy/productive worker thesis. In Academy of Management Proceedings. 1, 364-368

Yim, BCK, Zou, LW, Chan, KW (2018). Service-Sales Ambidexterity: A Multi-Level Analysis on the Underlying Processes of Its Influences on Satisfaction and Performance Outcomes for Employees and Customers. Frontiers in Service Conference, Austin

Table 1 Descriptive Statistics of job satisfaction of food industry

\begin{tabular}{|ll|c|c|c|}
\hline & JS32 & JS33 & JS34 \\
\hline \multirow{2}{*}{$\mathrm{N}$} & $\begin{array}{l}\text { Valid } \\
\text { Missing }\end{array}$ & 395 & 395 & 395 \\
\cline { 2 - 4 } & 0 & 0 & 0 \\
\hline Mean & 5.0253 & 5.4582 & 5.7266 \\
\hline Std. Deviation & .92586 & .89281 & 1.09274 \\
\hline Minimum & 1.00 & 2.00 & 2.00 \\
\hline Maximum & 7.00 & 7.00 & 7.00 \\
\hline
\end{tabular}

Table 2 Item Statistics of job satisfaction of food industry

I am satisfied with my job

I am satisfied with what I achieve at work

I feel good at work

\begin{tabular}{|c|c|c|}
\hline Mean & Std. Deviation & $\mathrm{N}$ \\
\hline 5.0253 & .92586 & 395 \\
5.4582 & .89281 & 395 \\
5.7266 & 1.09274 & 395 \\
\hline
\end{tabular}


Table 3 Reliability Statistics of job satisfaction

\begin{tabular}{|c|c|}
\hline Cronbach's Alpha & N of Items \\
\hline .830 & 3 \\
\hline
\end{tabular}

Table 4 Correlations of job satisfaction of food industry

\begin{tabular}{|c|c|c|c|c|c|c|c|}
\hline & & js & $\mathrm{ad}$ & Ac & wi & $\mathrm{r}$ & $\mathrm{G}$ \\
\hline \multirow{4}{*}{ js } & Pearson Correlation & 1 & & & & & \\
\hline & Sig. (2-tailed) & & & & & & \\
\hline & $\mathrm{N}$ & 395 & & & & & \\
\hline & Pearson Correlation & $.387^{* *}$ & 1 & & & & \\
\hline \multirow[t]{3}{*}{$\mathrm{ad}$} & Sig. (2-tailed) & .000 & & & & & \\
\hline & $\mathrm{N}$ & 395 & 395 & & & & \\
\hline & Pearson Correlation & $.391^{* *}$ & $.660^{* *}$ & 1 & & & \\
\hline \multirow[t]{3}{*}{$\mathrm{ac}$} & Sig. (2-tailed) & .000 & .000 & & & & \\
\hline & $\mathrm{N}$ & 395 & 395 & 395 & & & \\
\hline & Pearson Correlation & $.519^{* *}$ & $.566^{* *}$ & $.605^{* *}$ & 1 & & \\
\hline \multirow[t]{3}{*}{ wi } & Sig. (2-tailed) & .000 & .000 & .000 & & & \\
\hline & $\mathrm{N}$ & 395 & 395 & 395 & 395 & & \\
\hline & Pearson Correlation & $.506^{* *}$ & $.467^{* *}$ & $.551^{* *}$ & $.825^{* *}$ & 1 & \\
\hline \multirow[t]{3}{*}{$\mathrm{r}$} & Sig. (2-tailed) & .000 & .000 & .000 & .000 & & \\
\hline & $\mathrm{N}$ & 395 & 395 & 395 & 395 & 395 & \\
\hline & Pearson Correlation & $.488^{* *}$ & $.463^{* *}$ & $.578^{* *}$ & $.771^{* *}$ & $.863^{* *}$ & 1 \\
\hline \multirow[t]{2}{*}{ g } & Sig. (2-tailed) & .000 & .000 & .000 & .000 & .000 & \\
\hline & $\mathrm{N}$ & 395 & 395 & 395 & 395 & 395 & 395 \\
\hline
\end{tabular}

**. Correlation is significant at the 0.01 level (2-tailed).

Table 5 Correlations of job satisfaction and employee performance

\begin{tabular}{|c|c|c|c|}
\hline & & dep & js \\
\hline \multirow{3}{*}{ dep } & Pearson Correlation & 1 & $.701^{* *}$ \\
\hline & Sig. (2-tailed) & & .000 \\
\hline & $\mathrm{N}$ & 395 & 395 \\
\hline \multirow{3}{*}{ Js } & Pearson Correlation & $.701^{* *}$ & 1 \\
\hline & Sig. (2-tailed) & .000 & \\
\hline & $\mathrm{N}$ & 395 & 395 \\
\hline
\end{tabular}

**. Correlation is significant at the 0.01 level (2-tailed). 
Tables 6 of multiple regressions of intrinsic factors and job satisfaction of food industry Model Summary

\begin{tabular}{|l|r|r|r|c|}
\hline Model & R & R Square & Adjusted R Square & Std. Error of the Estimate \\
\hline 1 & $.762^{\mathrm{a}}$ & .581 & .580 & .03324 \\
\hline
\end{tabular}

a. Predictors: (Constant), g, r, ac, ad, wi

b. Dependent Variable: js

ANOVAa

\begin{tabular}{|ll|c|c|c|c|c|}
\hline & Model & Sum of Squares & df & Mean Square & F & Sig. \\
\hline \multirow{2}{*}{1} & Regression & 6.637 & 5 & 1.327 & 1201.075 & $.000^{\mathrm{b}}$ \\
& Residual & 4.795 & 389 & .001 & & \\
& Total & 11.432 & 394 & & & \\
\hline
\end{tabular}

a. Dependent Variable: js

b. Predictors: (Constant), g, r, ac, ad, wi

Coefficients

\begin{tabular}{|c|c|c|c|c|c|c|c|}
\hline \multirow[t]{2}{*}{ Model } & \multicolumn{2}{|c|}{ Unstandardized Coefficients } & \multirow{2}{*}{$\frac{\text { Standardized Coefficients }}{\text { Beta }}$} & \multirow[t]{2}{*}{$\mathrm{t}$} & \multirow[t]{2}{*}{ Sig. } & \multicolumn{2}{|c|}{ Collinearity Statistics } \\
\hline & $\mathrm{B}$ & Std. Error & & & & Tolerance & VIF \\
\hline (Constant) & .075 & .015 & & 4.896 & .000 & & \\
\hline Ad & .092 & .015 & .064 & 6.336 & .000 & .954 & 1.048 \\
\hline $\mathrm{Ac}$ & .103 & .009 & .111 & 11.191 & .000 & .986 & 1.014 \\
\hline $\mathrm{Wi}$ & .210 & .018 & .237 & 11.685 & .000 & .234 & 4.272 \\
\hline $\mathrm{R}$ & .028 & .014 & .020 & 1.940 & .052 & .942 & 1.062 \\
\hline $\mathrm{G}$ & .476 & .018 & .531 & 26.058 & .000 & .233 & 4.292 \\
\hline
\end{tabular}

a. Dependent Variable: js

Tables 7 of multiple regression of job satisfaction and employee performance of food industry Model Summary

\begin{tabular}{|c|c|c|c|c|}
\hline Model & $\mathrm{R}$ & R Square & Adjusted R Square & Std. Error of the Estimate \\
\hline 1 & $.993^{\mathrm{a}}$ & .986 & .986 & .00616 \\
\hline
\end{tabular}

a. Predictors: (Constant), js

b. Dependent Variable: dep

ANOVA ${ }^{\mathrm{a}}$

\begin{tabular}{|cc|c|c|c|c|c|}
\hline & Model & Sum of Squares & df & Mean Square & F & Sig. \\
\hline \multirow{4}{*}{1} & Regression & 11.207 & 1 & 11.207 & 295680.597 & $.000^{\mathrm{b}}$ \\
& Residual & .165 & 393 & .000 & & \\
\hline
\end{tabular}

a. Dependent Variable: dep

b. Predictors: (Constant), js

Coefficients $^{\mathrm{a}}$

\begin{tabular}{|c|c|c|c|c|c|c|c|}
\hline \multirow{2}{*}{ Model } & \multicolumn{2}{|c|}{$\begin{array}{c}\text { Unstandardized } \\
\text { Coefficients }\end{array}$} & \multirow{2}{*}{$\begin{array}{c}\begin{array}{c}\text { Standardized } \\
\text { Coefficients }\end{array} \\
\text { Beta }\end{array}$} & \multirow{2}{*}{$\mathrm{t}$} & \multirow{2}{*}{ Sig. } & \multicolumn{2}{|c|}{ Collinearity Statistics } \\
\hline & B & $\begin{array}{l}\text { Std. } \\
\text { Error }\end{array}$ & & & & Tolerance & VIF \\
\hline $\begin{array}{cc} & \text { (Constant) } \\
\text { js }\end{array}$ & $\begin{array}{l}.007 \\
.990\end{array}$ & $\begin{array}{l}.001 \\
.002\end{array}$ & .993 & $\begin{array}{c}5.489 \\
543.765\end{array}$ & $\begin{array}{l}.000 \\
.000\end{array}$ & 1.000 & 1.000 \\
\hline
\end{tabular}

a. Dependent Variable: dep 